\title{
ANTI-MYCOBACTERIUM TUBERCULOSIS ACTIVITY OF FUNGUS PHOMOPSIS STIPATA
}

\author{
Karina Andrade de Prince ${ }^{1,3}$, Renata Sordi ${ }^{2}$, Fernando Rogério Pavan ${ }^{1}$, Adolfo Carlos Barreto Santos ${ }^{1}$, Angela R. Araujo ${ }^{2}$, \\ Sergio R.A. Leite ${ }^{2}$, Clarice Q. F. Leite ${ }^{1 *}$
}

\author{
${ }^{1}$ Faculdade de Ciências Farmacêuticas, Universidade Estadual Paulista, Araraquara, SP, Brasil; ${ }^{2}$ Instituto de Química, \\ Universidade Estadual Paulista, Araraquara, SP, Brasil; ${ }^{3}$ Faculdades Integradas Pitágoras, Montes Claros, MG, Brasil.
}

Submitted: July 22, 2010; Approved: June 06, 2011.

\begin{abstract}
Our purpose was to determine the anti-Mycobacterium tuberculosis activity of the metabolites produced by the endophitic fungus Phomopsis stipata (Lib.) B. Sutton, (Diaporthaceae), cultivated in different media. The antimycobacterial activity was assessed through the Resazurin Microtiter Assay (REMA) and the cytotoxicity test performed on macrophage cell line. The extracts derived from fungi grown on Corn Medium and Potato Dextrose Broth presented the smallest values of Minimum Inhibitory Concentration (MIC) and low cytotoxicity, which implies a high selectivity index. This is the first report on the chemical composition and antitubercular activity of metabolites of $P$. stipata, as well as the influence of culture medium on these properties.
\end{abstract}

Key words: Phomopsis stipata, antimycobacterial activity, Mycobacterium tuberculosis.

\section{INTRODUCTION}

Tuberculosis (TB) is a respiratory disease caused by Mycobacterium tuberculosis, transmitted from person to person, which affects approximately $32 \%$ of world population. In Brazil, 80.000 cases are registered annually with incidence rate of $37,1 / 100,000$ inhabitants, according to data from the Ministry of Health (9). Among the infected individuals in the world, about eight million a year develop active TB and nearly two million die (33). Advancements in health care facilities offered a goal to eradicate tuberculosis (TB) by the end of the 20th century, but it reemerged because of the global resistance against antitubercular drugs (22). The advent multidrug resistance (MDR), extensive drug resistance (XDR) infection, concerns health authorities around the world, especially in developing countries, where the situation is more severe. The emergence of strains resistant to most drugs currently used as antituberculosis makes urgent the search for new synthetic or natural agents against this disease (35).

One approach to this is to search in the nature, especially for the rich flora of the tropics and its endophytic fungi. Natural products and/or their semi-synthetic derivatives can lead to novel antimycobacterial drugs and might have important role in the chemotherapy of tuberculosis in the future (26). Thus, some reports have demonstrated the importance of performing screening of natural products with activity against M. tuberculosis $(17,13,20,32)$.

The vegetal species Styrax camporum Pohl (Styracaceae) occurs predominantly in Brazilian central cerrado (8), which is one of the major biogeographical regions in the world, with 
more than 7000 native species of vascular plants (21). This plant is widely used in folk medicine to treat gastric and intestinal diseases. Different authors evaluated the antiulcerative potentiality and toxicity of crude extracts and fractions of this plant and their effectiveness to treat peptic ulcer $(2,3)$ as well its antioxidant activity $(15)$.

The endophytic fungi from genus Phomopsis Sacc. \& Roum., (Diaporthaceae) are known as rich sources of secondary bioactive metabolites of different chemical natures (29, 30). A Phomopsis sp isolated from Thailand forest presented metabolites with anti- $M$. tuberculosis activity (5). This genus of endophyte had never before been isolated from the Brazilian cerrado plants.

The present study describes the isolation of $P$. stipata (Lib.) B. Sutton, (Diaporthaceae) from leaves of $S$. camporum and the determination of the anti-M. tuberculosis activity, cytotoxicity and selectivity index (SI) of crude extracts this endophytic fungus, cultured on different media. We also identified the main classes of compounds present in extracts by High-performance liquid chromatography fractionation and analysis by Nuclear magnetic resonance (NMR).

\section{MATERIAL AND METHODS}

\section{Plant Material}

The leaves from species plant $S$. camparum were collected at Ecological Experimental Station of Mogi-Guaçu, Campininha Farm $\left(22^{\circ} 17^{\prime} \mathrm{S}, 4^{\circ} 07^{\prime} \mathrm{W}\right)$, São Paulo State, Brazil, and identified by Dr. Inês Cordeiro (Botanic Institute of São Paulo Agriculture Secretary). The specimen was classified and deposited in the herbarium of the same institution under the number Young 07-SP.

\section{Isolation of the Endophytic Fungus}

For isolation of the endophytic fungus, adult and healthy leaves were selected and submitted to surface sterilization. They were first washed with water and soap, and then immersed in a $1 \%$ aqueous sodium hypochlorite solution for 5 min and aqueous ethanol (70 \%) for $1 \mathrm{~min}$. A second washing with water and soap was performed and finally the leaves were immersed in sterile water for $10 \mathrm{~min}$. The sterilized leaves were cut into $2 \mathrm{~cm}^{2}$ pieces and deposited on Petri dishes containing Potato Dextrose Agar (PDA) and gentamicin sulfate $(0.5 \mathrm{ug} / \mathrm{mL}), 4$ pieces for dish. The material was incubated at $25^{\circ} \mathrm{C}$ for 10 days and the endophyte $P$. stipata was isolated by replication and preserved in sterile water (19). The fungus was identified by Dr. Ludwig H. Pfenning using rRNA internal transcribed spacer (ITS) region and deposited in the Micology Collection of the Federal University of Lavras, Lavras, MG, Brazil.

\section{Cultive of the Endophytic Fungus}

The fungus $P$. stipata was cultivated in different commercial media from Difco (Difco ${ }^{\mathrm{tm}}$ laboratories, Detroit, MI, USA) (Potato Dextrose Broth - PD, Yeast Medium - YM, Nutrient Broth - NB and Czapek Medium - CZ) and in a homemade corn medium (ECorn). The commercial media were prepared as recommended by the manufacturer (Difco ${ }^{\mathrm{tm}}$ ) and the corn medium by 3 times autoclavation of $90 \mathrm{~g}$ of corn in 80 $\mathrm{mL}$ of distilled water. The culture media were maintained, under agitation, in an incubator for 28 days at $25^{\circ} \mathrm{C}$. All cultivation was done in duplicate. After this, the cultures containing the secondary metabolites secreted by the fungus were separated from mycelia by vacuum filtration and submitted to extraction with ethyl acetate (Synth ${ }^{\circledR}$ laboratories, Diadema, SP, Brazil). The ethyl acetate solutions were evaporated under reduced pressure, resulting the following masses of the dry crude extracts, in mg: 57.2 for EPD, 20.1 for EYM, 19.2 for ENB, 17.9 for ECZ, and 67.0 for ECorn.

\section{Chemical analysis}

Each crude extract was submitted to RP-HPLC-DAD (Reverse Phase - High Performance Liquid Chromatography Diode Array Detector) with analytical column Phenomenex $\mathrm{C} 18$ in exploratory gradient, using $\mathrm{MeOH}: \mathrm{H}_{2} \mathrm{O}(95: 5 \mathrm{w} / \mathrm{w})$ to $(0: 100 \mathrm{w} / \mathrm{w})$ as elution system, flow of $1.0 \mathrm{~mL} / \mathrm{min}$ (total time of $40 \mathrm{~min}$ ) and detection at $\lambda=253 \mathrm{~nm}$. The extracts were also 
analyzed by NMR spectroscopy The NMR spectra in deuterated chloroform $\left(\mathrm{CDCl}_{3}\right)$ were obtained using a Varian INOVA 500 spectrometer, operating at $500 \mathrm{MHz}$ for ${ }^{1} \mathrm{H}$ and at $150 \mathrm{MHz}$ for ${ }^{13} \mathrm{C}$.

\section{Anti - M. tuberculosis activity assay}

The anti- $M$. tuberculosis activity of the crude extracts (ECorn, EPD, ECZ, EYM and ENB) were determined in triplicate using the Resazurin Microtiter Assay (REMA) as analytical method $(24,34)$. Stock solutions of the tested compounds were prepared in dimethyl sulfoxide (DMSO) and diluted in broth medium Middlebrook 7 H9 (Difco), supplemented with oleic acid, albumin, dextrose, and catalase (OADC enrichment - BBL/Becton-Dikinson, Sparks, MD, USA), to obtain final drugs concentration ranges of 15.6 to $2000 \mu \mathrm{g} / \mathrm{mL}$. The isoniazid was dissolved in distilled water, as recommended by the manufacturer (Difco laboratories, Detroit, MI, USA), and used as a standard drug. MTB $\mathrm{H}_{37} \mathrm{Rv}$ ATCC 27294 was grown for 7 to 10 days in Middlebrook 7 H9 broth supplemented with OADC, plus $0.05 \%$ Tween 80 to avoid clumps. Cultures were centrifuged for $15 \mathrm{~min}$ at $3,150 \mathrm{x} \mathrm{g}$, washed twice, and resuspended in phosphate-buffered saline and aliquots were frozen at $-80^{\circ} \mathrm{C}$. After 2 days, an aliquot was thawed to determine the viability and the CFU after freezing. MTB $\mathrm{H}_{37} \mathrm{Rv}$ (ATCC 27294) was thawed and added to the test compounds, yielding a final testing volume of $200 \mu \mathrm{L}$ with $2 \times 10^{4} \mathrm{CFU} / \mathrm{mL}$. Microplates with serial dilutions of each compound were incubated for 7 days at $37^{\circ} \mathrm{C}$, after resazurin (Sigma-Aldrich $^{\circledR}$ St. Louis, MO, USA) was added to test viability. Wells that turned from blue to pink, with the development of fluorescence, indicated growth of bacterial cells, while maintenance of the blue colour indicated bacterial inhibition $(24,27)$. The fluorescence was read $(530 \mathrm{~nm}$ excitation filter and $590 \mathrm{~nm}$ emission filter) in a SPECTRAfluor Plus (Tecan $^{\circledR}$ Männedorf, Switzerland) microfluorimeter. The Minimum Inhibitory Concentration (MIC) was defined as the lowest concentration resulting in $90 \%$ inhibition of growth of MTB (6). As a standard test, the MIC of isoniazid was determined on each microplate. The acceptable range of isoniazid MIC is from 0.015 to $0.03 \mu \mathrm{g} / \mathrm{mL}$ $(24,27)$.

\section{Cytotoxicity assay}

The in vitro cytotoxicity $\left(\mathrm{IC}_{50}\right)$ assay was determined on macrophage cell line J774. The cells were routinely maintained in Complete Medium (RPMI-1640 supplemented with 10\% heat inactivated fetal bovine serum (FBS); $100 \mathrm{U} / \mathrm{mL}$ penicillin and $100 \mu \mathrm{g} / \mathrm{mL}$ streptomycin), at $37^{\circ} \mathrm{C}$ in a humidified $5 \% \mathrm{CO}_{2}$ atmosphere. After reaching confluence, the cells were detached and counted. For the cytotoxicity assay, 1 x $10^{5}$ cells $/ \mathrm{mL}$ were seeded in $200 \mu \mathrm{L}$ of complete medium in 96-well plates (NUNC $^{\mathrm{tm}}$, Thermo Fisher Scientific, USA). The plates were incubated at $37^{\circ} \mathrm{C}$ under a $5 \% \mathrm{CO}_{2}$ atmosphere for $24 \mathrm{~h}$, to allow cell adhesion prior to drug testing. The crude extracts (ECorn, EPD and ECZ) were dissolved in DMSO and submitted at two fold dilution from 2000 to $15.6 \mu \mathrm{g} / \mathrm{mL}$. Cells were exposed to the compounds for a $24 \mathrm{~h}$ period. Resazurin solution was added to cell cultures and incubated for $6 \mathrm{~h}$. The fluorescence measurements $(530 \mathrm{~nm}$ excitation filter and 590 $\mathrm{nm}$ emission filter) were performed in a SPECTRAfluor Plus (Tecan) microfluorimeter. The $\mathrm{IC}_{50}$ value was defined as the highest drug concentration at which $50 \%$ of the cells are viable relative to the control $(1,28,27)$.

\section{Selectivity Index}

The selectivity index (SI) was obtained by the ratio between $\mathrm{IC}_{50}$ and MIC values (23).

\section{General}

${ }^{1} \mathrm{H}$ NMR (500 MHz) experiments were recorded on a VARIAN DRX-500 spectrometer, using the non-deuterated signal as reference. TLC was performed using Merck silica gel 60 (230 mesh) and precoated silica gel $60 \mathrm{PF}_{254}$. Spots on TLC plates were visualized under UV light and by spraying with anisaldehyde- $\mathrm{H}_{2} \mathrm{SO}_{4}$ reagent followed by heating at $120{ }^{\circ} \mathrm{C}$. Analytical HPLC-DAD was carried out on a Varian (Palo Alto, CA, USA) ProStar system consisting of a ternary pump model 240, a diode array detector model 330 and an auto-sampler 
model 410 , controlled by a Star chromatography workstation (version 5.3), using a Phenomenex C18 column (250 mm x 4.6 $\mathrm{mm}, 5 \mu \mathrm{m})$.

\section{RESULTS AND DISCUSSION}

The results of the mass yield in mg of crude extracts and the biological activity of extracts are presented in Table 1. The ECorn showed the best mass yield of $67.0 \mathrm{mg}$ and also presented the best activity against $M$. tuberculosis with MIC of $31.25 \mu \mathrm{g} / \mathrm{mL}$, followed by EPD (57.2 $\mathrm{mg}$ and MIC of 62.5 $\mu \mathrm{g} / \mathrm{mL}), \mathrm{ECZ}(17.9 \mathrm{mg}$ and MIC of $125 \mu \mathrm{g} / \mathrm{mL})$. For others extracts it was observed smaller mass yield and MIC of 250 $\mu \mathrm{g} / \mathrm{mL}$. The results indicate larger extract yield from Corn medium that probably also provided larger production of bioactive metabolites in this medium when the $P$. stipata was cultivated at $25^{\circ} \mathrm{C}$. Based on this, we emphasize that the composition of the medium influences the metabolites production.

Analysis of the RP-HPLC-DAD and ${ }^{1} \mathrm{H}$ NMR data suggested the presence of koninginins, a class of hexaketides, which are natural products belonging of the group of poliketides. Other compounds of this group, the koninginins A$\mathrm{G}$, which are octaketides, were previously isolated from fungi of Trichoderma genus $(10,11,12,16,25)$.

For plants extracts, Tosun et al. (31) considered inactive the extracts that could not prevent M. tuberculosis growth up to a concentration of $200 \mu \mathrm{g} / \mathrm{mL}$ and according to Cantrell et al. (4) the isolated compounds that exhibit a MIC of $64 \mu \mathrm{g} / \mathrm{mL}$ or lower are defined as active. Thus, the crude extracts obtained here, mainly that coming from EPD and ECorn, are as good as a promising isolated compound. Although the MIC values obtained here are larger than that of isoniazid $(0.03 \mu \mathrm{g} / \mathrm{mL})$, these inhibitory concentrations are comparable to the MIC of pyrazinamide (another first-line antitubercular drug) with MIC of $50-100 \mu \mathrm{g} / \mathrm{mL}$ (6). The promising activity of the secondary metabolites from endophytic fungi was verified by Silva et al. $(29,30)$, against different microorganisms. From Phomopsis $\mathrm{sp}$ isolated of Thailand plants, Isaka et al. (14) founded two new bioactive secondary metabolites (Phomoxanthones A and B) with significant in vitro antimycobacterial activity (MIC of 0.5 and $6.25 \mu \mathrm{g} / \mathrm{mL}$ ) and Chomcheon et al. (5) identified 3Nitropropionic acid with MIC of $3.3 \mu \mathrm{M}$. In our case, the activity of the extracts can be attributed to the presence of koninginins, identified as their major compounds. The antibacterial and mycotoxical activities of koninginins were already described $(10,11,12,25,16)$. However, no mention of antimycobacterial activity associated to such compounds was reported in the last 13 years $(7,8)$.

The crude extracts of ECorn, EPD and ECZ also presented low cytotoxicity and the SI analysis showed that these crude extracts are 4 to 8 times more active against $M$. tuberculosis than against the macrophage cells (Table 1).

Table 1. Results of Minimum Inhibitory Concentration (MIC), in vitro Citotoxicity ( $\mathrm{IC}_{50}$ ), Selectivity Index (SI) and mass yield of crude extracts produced by Phomopsis stipata

\begin{tabular}{|c|c|c|c|c|}
\hline \multirow{2}{*}{ Crude Extracts } & Mass Yield & MIC & $\mathbf{I C}_{50}$ & SI \\
\hline & (mg) & $(\mu \mathrm{g} / \mathrm{mL})$ & $(\mu \mathrm{g} / \mathrm{mL})$ & $\left(\mathrm{IC}_{50} / \mathrm{MIC}\right)$ \\
\hline ECorn & 67.0 & 31.25 & $>250.0$ & $\leq 8$ \\
\hline EPD & 57.2 & 62.5 & $>500.0$ & $\leq 8$ \\
\hline $\mathrm{ECZ}$ & 17.9 & 125.0 & $>500.0$ & $\leq 4$ \\
\hline EYM & 20.1 & 250.0 & ND & ND \\
\hline ENB & 19.2 & 250.0 & ND & ND \\
\hline $\begin{array}{c}\text { Isoniazid } \\
\text { (Standard drug) }\end{array}$ & & 0.03 & ND & ND \\
\hline
\end{tabular}




\section{CONCLUSION}

The endophytic fungus $P$. stipata produced a greater quantity of bioactive metabolites when cultured in PD and Corn media, and these metabolites have showed promising anti-MTB activity. Thus, this work reinforces the affirmation about the quantity and production of the metabolite being media-dependent. RP-HPLC-DAD and 1H NMR data suggested the presence of koninginins in these secondary metabolites which can explain the better biological activity. Additionaly, low toxicity on macrophage cells and high SI values was observed recommending further studies to investigate other biological activities.

\section{ACKNOWLEDGEMENTS}

This study was supported by CAPES and FAPESP (Fundação de Amparo à Pesquisa do Estado de São Paulo) process $n^{\circ} 2009 / 06499-1$, for grants to F. R. Pavan (process $n^{\circ}$ 06/50680, 2008/10390-2 and 2011/11593-7).

\section{REFERENCES}

1. Ahmed, S.A.; Gogal, R.M.; Walsh, J. (1994). A new rapid and simple non-radioactive assay to monitor and determine the proliferation of lymphocytes: An alternative to $[3 \mathrm{H}]$ thymidine incorporation assay. $J$. Immunol. Methods. 170, 211-224.

2. Bacchi, E.M.; Sertié, J.A.A. (1994). Antiulcer action of Styrax camporum and Caesalpinia ferrea in rats. Planta. Med. 60, 118-120.

3. Bacchi, E.M.; Sertié, J.A.A.; Villa, N.; Katz, H. (1995). Antiulcer action and toxicity of Styrax camporum and Caesalpinia ferrea. Planta. Med. 61, 204-207.

4. Cantrell, C.L.; Franzblau, S.G.; Fischer, N.H. (2001). Antimycobacterial plant terpenoids. Planta. Med. 67, 685-694.

5. Chomcheon, P.; Wiyakrutta, S.; Sriubolmas, N.; Ngamrojanavanich, N.; Isarangkul, D.; Kittakoop, P. (2005). 3-Nitropropionic acid (3-NPA), a potent antimycobacterial agent from endophytic fungi: Is 3-NPA in some plants produced by endophytes?. J. Nat. Prod. 68, 1103-1105.

6. Collins, L.A.; Franzblau, S.G. (1997). Microplate alamar blue assay versus BACTEC 460 system for high-throughput screening of compounds against Mycobacterium tuberculosis and Mycobacterium avium. Antimicrob. Agents Chemother. 41, 1004-1009.

7. Copp, B.R. (2003). Antimycobacterial natural products. Nat. Prod. Rep.
20, 535-557.

8. Copp, B.R. \& Pearce, A.N. (2007). Natural product growth inhibitors of Mycobacterium tuberculosis. Nat. Prod. Rep. 24, 278-297.

9. Cruz, H.L.A.; Montenegro, R.A.; Lima, J.F.A.; Poroca, D.R.; Lima, J.F.C.; Montenegro, L.M.L.; Crovella, S.; Schindler, H.C. (2010). Evaluation of a nested-pcr for Mycobacterium tuberculosis detection in blood and urine. Braz. J. Microbiol. 42, 321-329.

10. Cutler, H.G.; Himmelsbach, D.S.; Arrendale, R.E.; Cole, P.D.; Cox, R.D. (1989). Koninginin A: a novel plant growth regulator from Trichoderma koningii. Agric. Biol. Chem. 53, 2604-2611.

11. Cutler, H.G.; Himmelsbach, D.S.; Yagen, B.; Arrendale, R.F.; Jacyno, J.M.; Cole, P.D.; Cox, R.H. (1991). Koninginin B: a biologically active congener of Koninginin A from Trichoderma koningii. J. Agric. Food. Chem. 39, 977-980.

12. Cutler, H.G.; Cutler, S.J.; Ross, S.A.; El Sayed, K.; Dugan, F.M.; Bartlett, M.G.; Hill, A.A.; Hill, R.A.; Parker, S.R. (1999). Koninginin G, a new metabolite from Trichoderma aureoviride. J. Nat. Prod. 62, 137139.

13. Higuchi CT, Sannomiya M, Pavan FR, Leite SRA, Sato DN, Franzblau SG, Sacramento LVS, Vilegas W, Leite CQF . Byrsonima fagifolia Niedenzu Apolar Compounds with Antitubercular Activity. Evid Based Complement Alternat Med [doi:10.1093/ecam/nen077]. 2008 Dec [cited 2010 Feb 01]; [about 5 p.]. Available from: http://ecam.oxfordjournals.org/cgi/reprint/nen077v1.

14. Isaka, M.; Jaturapat, A.; Rukseree, K.; Danwisetkanjana, K.; Tanticharoen, M.; (2001). Phomoxanthones A and B, novel xanthone dimers from the endophytic fungus Phomopsis species. J. Nat. Prod. 64, 1015-1018.

15. La Casa, C.; Villegas, I.; Alarcón de la Lastra,C.; Motilva, V.; Martín, C.M. (2000). Evidence for protective and antioxidant properties of rutin, a natural flavone, against ethanol induced gastric lesions. $J$. Ethnopharmacol. 71, 45-53.

16. Liu, G.; Wang, Z. (1999). First total synthesis of (+)-Koninginin D. Chem. Commun. 1, 1129-1130.

17. Lopes, F.C.M.; Placeres, M.C.P.; Jordão Junior, C.M.; Higuchi, C.T.; Rinaldo, D.; Vilegas, W.; Leite, C.Q.F.; Carlos, I.Z. (2007). Immunological and microbiological sctivity of Davilla elliptica ST. Hill (Dilleniaceae) against Mycobacterium tuberculosis. Mem. Inst. Oswaldo Cruz. 102, 769-772.

18. Lorenzi, H. (2000). Árvores brasileiras - Manual de identificação e cultivo de plantas arbóreas nativas do Brasil, Vol. I, Plantarum, Nova Odessa.

19. Maier, W.; Hammer, K.; Dammann, U.; Schulz, B.; Strack, D. (1997). Accumulation of sesquiterpenoid cyclohexenone derivatives induced by an arbuscular mycorrhizal fungus in members of the Poaceae. Planta. Med. 202, 36-42.

20. McCutcheon, A.R.; Stokes, R.W.; Thorson, L.M.; Ellis, S.M.; Hancock, R.E.W.; Towers G.H.N. (1997). Anti-mycobacterial screening of British Columbian medicinal plants. Pharm. Biol. 35, 77-83. 
21. Mendonça, R.C.; Felfili, J.M.; Walter, B.M.T.; Silva Jr, M.C. (1998) Flora Vascular do Cerrado, In. Sano SM, Almeida SP, Cerrado: Ambiente e Flora. Embrapa, Planaltina.

22. Nazir, T.; Rassol, M.H.; Hameed, A.; Ahmad, B.; Qureshi, J.A. (2010). Ethambutol resistance of indigenous Mycobacterium tuberculosis isolated from human. Braz. J. Microbiol. 41, 1065-1069.

23. Orme, I.; Secrist, J.; Anathan, S.; Kwong, C.; Maddry, J.; Reynolds, R.; Poffenberger, A.; Michael, M.; Miller, L.; Krahenbuh, J.; Adams, L.; Biswas, A.; Franzblau, S.G.; Rouse, D.; Winfield, D.; Brooks, J. (2001). Search for new drugs for treatment of tuberculosis. Tuberculosis drug screening program. Antimicrob. Agents. Chem. 45, 1943-1946.

24. Palomino, J.C.; Martin, A.; Camacho, M.; Guerra, H.; Swings, J.; Portaels, F. (2002). Resazurin microtiter assay plate: Simple and inexpensive method for detection of drug resistance in Mycobacterium tuberculosis. Antimicrob. Agents. Chem. 46: 2720-2722.

25. Parker, S.R.; Cutler, H.G.; Schreiner, P.R. (1995). Koninginin C: a biologically active natural product from Trichoderma koningii. Biosci. Biotechnol. Biochem. 59, 1126-1127.

26. Pavan, F.R. ; Leite, C.Q.F. ; Coelho, R.G. ; Coutinho, I.D. ; Honda, N.K. ; Cardoso, C.A.L. ; Vilegas, W. ; Leite, S.R.A. ; Sato, D.N. (2009). Evaluation of anti-Mycobacterium tuberculosis activity of Campomanesia adamantium (MYRTACEAE). Quim. Nova. 32, 12221226.

27. Pavan, F.R..; Maia, P.I.; Leite, S.R.; Deflon, V.M.; Batista, A.A.; Sato, D.N.; Franzblau, S.G.; Leite, C.Q.F. (2010). Thiosemicarbazones, semicarbazones, dithiocarbazates and hydrazide/hydrazones: AntiMycobacterium tuberculosis activity and cytotoxicity. Eur. J. Med. Chem. 45, 598-601.

28. Santos, J.L.; Yamasaki, P.R.; Chin, C.M.; Takashi, C.H.; Pavan, F.R.; Leite, C.Q.F. (2009). Synthesis and in vitro anti-Mycobacterium tuberculosis activity of a series of phthalimide derivatives. Bioorg. Med. Chem. 17, 3795-3799.

29. Silva, G.H.; Teles, H.L.; Trevisan, H.C.; Young, M.C.M.; Pfenning, L.H.; Eberlin, M.N.; Haddad, R.; Costa-Neto, C.M.; Bolzani, V.S.; Araújo, A.R. (2005). New bioactive metabolites produced by Phomopsis cassiae, an endophytic fungus in Cassia spectabilis. J. Braz. Chem. Soc. 16, 1463-1466.

30. Silva, G.H.; Teles, H.L.; Zanardi, L.M.; Young, M.C.M.; Eberlin, M.N.; Haddad, R.; Pfenning, L.H.; Costa-Neto, C.M.; Gamboa, I.C.; Bolzani, V.S.; Araújo, A.R. (2006). Cadinane sesquiterpenoids of Phomopsis cassiae, an endophytic fungus associated with Cassia spectabilis (Leguminosae). Phytochemistry. 67, 1964-1969.

31. Tosun, F.; Kizilay, C.A.; Sener, B.; Vural, M.; Palittapongarnpim, P. (2004). Antimycobacterial screening of some Turkish plants. $J$. Ethnopharmacol. 95, 273-275a.

32. Tosun, F.; Kizilay, C.A.; Sener, B.; Vural, M.; Palittapongarnpim, P. (2005). The evaluation of plants from Turkey for in vitro antimycobacterial activity. Pharm. Biol. 43, 58-63b.

33. Tripathi, R.P.; Tewari, N.; Dwivedi, N.; Tiwari, V.K. (2004). Fighting tuberculosis: An old disease with new challenges. Med. Res. Rev. 25, 93131.

34. Von Groll, A.; Martin, A.; Portaels, F.; Silva, P.E.A.; Palomino, J.C. (2010). Growth kinetics of Mycobacterium tuberculosis measured by quantitative resazurin reduction assay: a tool for fitness studies. Braz. J. Microbiol. 41, 300-303.

35. WHO - World Health Organization 2007. Global tuberculosis control: surveillance, planning, financing. WHO Report [cited 2010 Jan 01]. Available from://www. who.int/tb/publications/global_report/2007/pdf/ full.pdf. 